\title{
Grensonderhandelingen in de vrije tijd
}

AUTEURS Karin Peters \& Lauren Wagner

FOTOGRAFIE Karin Peters

\section{Vrijetijdsbesteding in de publieke ruimte is niet voor iedereen even 'publiek'. Vrouwen ondervinden vaak meer beperkingen dan mannen wanneer zij zich in publieke ruimtes begeven, en dit geldt zeker ook voor moslima's in Europa. De vraag is hoe zij met deze beperkingen omgaan en of zij grenzen over- schrijden om zo bepaalde activiteiten te kunnen ondernemen.}

Hoewel publieke ruimtes fysiek voor iedereen openstaan - openbare parken en straten in de stad zijn immers toegankelijk voor iedereen - zijn er vele redenen waarom mensen worden uitgesloten of waardoor zij zich uitgesloten voelen. Ook openbare ruimtes die gebruikt worden voor vrijetijdsactiviteiten zijn onderhevig aan processen van in- en uitsluiting, van harmonie en conflict, van negatieve en positieve betrokkenheid zoals ook aangegeven door Aitchinson in 2001 en Bridge en Watson in 2002.

\section{Risicovolle en acceptabele plekken}

Volgens Scraton en Watson spreekt het bijna vanzelf dat openbare ruimtes seksegebonden, geseksualiseerd en geracialiseerde plekken zijn. De relatie tussen gender en de openbare ruimte is door Green en Singleton in 2006 beschreven in termen van het onderhandelen van risico's waarbij er vanuit wordt gegaan dat dominante groeperingen (vaak gender, etniciteit en klasse gerelateerd) minder risico's ondervinden dan andere groeperingen. In het algemeen wordt verondersteld dat vrouwen, en zeker ook moslima's, meer beperkingen ondervinden ten aanzien van hun keuzes in de vrije tijd en het bezoeken van publieke ruimtes. Als gevolg van deze risico's wordt hun keuzevrijheid begrensd. Deze begrenzing heeft een ruimtelijke en sociale component. De ruimtelijke component is bijvoorbeeld beschreven in de studie van Deem uit 1986 naar de vrije tijd van vrouwen in Milton Keynes. In deze studie wordt aangetoond dat er ruimtelijke ongelijkheid is tussen vrouwen en mannen als gevolg van de angst voor geweld en de macht van mannen ten aanzien van de vrijetijdsactiviteiten van vrouwen en de plekken waar vrouwen al dan niet naar toe kunnen gaan. Sociaal gezien wordt keuzevrijheid beperkt door praktische verantwoordelijkheden (huishouden en familie). Voor moslima's geldt bovendien dat zij beperkt kunnen zijn in hun mobiliteit omdat zij, zoals eerder aangegeven door Yücesoy in 2006, verantwoordelijk zijn voor het onderhouden van traditionele sociale codes. Denk daarbij aan 'eer' en 'vrouwendeugd'.

Echter, we moeten vrouwen niet alleen als potentiële slachtoffers in de openbare ruimte zien, maar ook als actoren die onderhandelen over geschikte ruimtes. Vrouwen overschrijden grenzen en kijken onder welke voorwaarden bepaalde ruimtes wel toegankelijk voor hen zijn. In deze bijdrage laten we zien hoe vrouwen onderhandelen over hun vrijetijdsbesteding. Centraal staat hoe vrouwen omgaan met diverse beperkingen, hoe zij omgaan met het stellen van prioriteiten, beperkingen, uitdagingen en risico's als ze hun vrije tijd buitenshuis willen invullen. We geven inzicht in hoe moslima's van Marokkaanse afkomst, woonachtig in Europa, diverse ruimtes in hun vrije tijd gebruiken en hoe keuzes worden gemaakt.

Dit artikel is gebaseerd op onderzoek onder Europese vrouwen van Marokkaanse afkomst. Veel van deze vrouwen zijn in Europa geboren en getogen of kwamen op jonge leeftijd naar Europa. Het onderzoek is uitgevoerd door middel van interviews en etnografisch veldwerk. In de volgende paragraaf beschrijven we enkele resultaten.

\section{Grenzen verleggen}

De Europese vrouwen van Marokkaanse afkomst maken gebruik van verschillende publieke ruimtes om hun vrije tijd door te brengen, maar zij geven ook aan dat er ruimtelijke en sociale grenzen zijn waardoor zij niet alle ruimtes bezoeken. Tegelijkertijd onderhandelen ze over bepaalde grenzen waarbij de vrouwen proberen een 
evenwicht te vinden tussen het eigen gevoel van fatsoen in de vrije tijd en het voldoen aan de verwachtingen van enerzijds een niet-moslim religieus-culturele meerderheid en van hun familie anderzijds. Dit vertaalt zich soms in het verleggen van grenzen door bepaalde ruimtes juist te bezoeken. Zo claimen de NederlandsMarokkaanse vrouwen bijvoorbeeld hun recht om aanwezig te zijn op vrijetijdsplekken die worden gezien als typisch 'Nederlands' of waarvan zij de indruk hebben dat zij daar niet gewenst zijn. Sommige vrouwen geven aan dat zij bewust toch voor deze plekken kiezen en maken hiermee ruimtelijk en sociale grenzen onderwerp van onderhandeling:

"Ja, ik laat me eigenlijk door niemand en door niets weghouden van iets, laat ik het zo zeggen. Als ik ergens moet zijn, met alle gevolgen van dien, dan doe ik dat. Ik vind het bijvoorbeeld altijd heel fijn om goede schoenen te kopen en dan moet je soms bij dure winkels zijn; daar wordt je ook weggekeken van 'alsof je dat niet kan betalen' Maar toch blijf ik daar komen en ik blijf netjes vragen of ze me willen helpen. Ja, en ik wil gewoon goede schoenen en dat zij daar dan zitten [...] ja zij hebben daar ook mee te leren leven. Ik vind dat zij ook gewoon moeten leren en dat zij ook weer anders naar mij kijken. Ik ben moslim en daar sta ik voor, en ik ben wie ik ben. Ik krijg bijvoorbeeld soms wel eens het advies om niet naar een bepaalde plek toe te gaan in Utrecht, maar dan wil ik juist naar die plek toe gaan! Zelfs als ik bijvoorbeeld zou horen van 'er werkt in dat clubhuis een racist' of wat dan ook, dan wil ik er juist naar toe en dan wil ik juist weten wie is de racist. Omdat ik zoiets heb van, ja ik hoef mezelf niet te bepreken omdat er één iemand de boel loopt te verzieken. Ik wil me gewoon niet laten beperken; door niets eigenlijk. Ik ben bijvoorbeeld een keer met een groep vrouwen naar een museum in Amsterdam geweest en toen kwam er ook een groep Nederlandse vrouwen en die fluisterden naar elkaar: "Mogen zij ook hier komen?", en ik zei terug in het Nederlands: "Hoezo? Mogen jullie ook hier komen van jullie mannen?"

\section{Sociale grenzen zijn van grote invloed op het gedrag van vrouwen}

Hoewel sommige plekken dus geclaimd worden door de dominante groep, kiezen deze Nederlands-Marokkaanse vrouwen er bewust voor deze plekken te bezoeken. Hiermee zorgen zij ervoor dat de grenzen niet worden gereconstrueerd.

Soms blijken deze sociale grenzen echter van grote invloed op het gedrag van de vrouwen. De grenzen blijken lastig te overschrijden en de vrouwen kiezen er dan voor om met de dominante verwachtingen rekening te houden door bepaald gedrag juist wel of niet te vertonen:

"Ik probeer me ook altijd goed te gedragen in de openbare ruimte; bijvoorbeeld niet een propje op de grond gooien, of op straat iets onfatsoenlijks doen. Ik let er wel op dat ik gewoon netjes ben en me

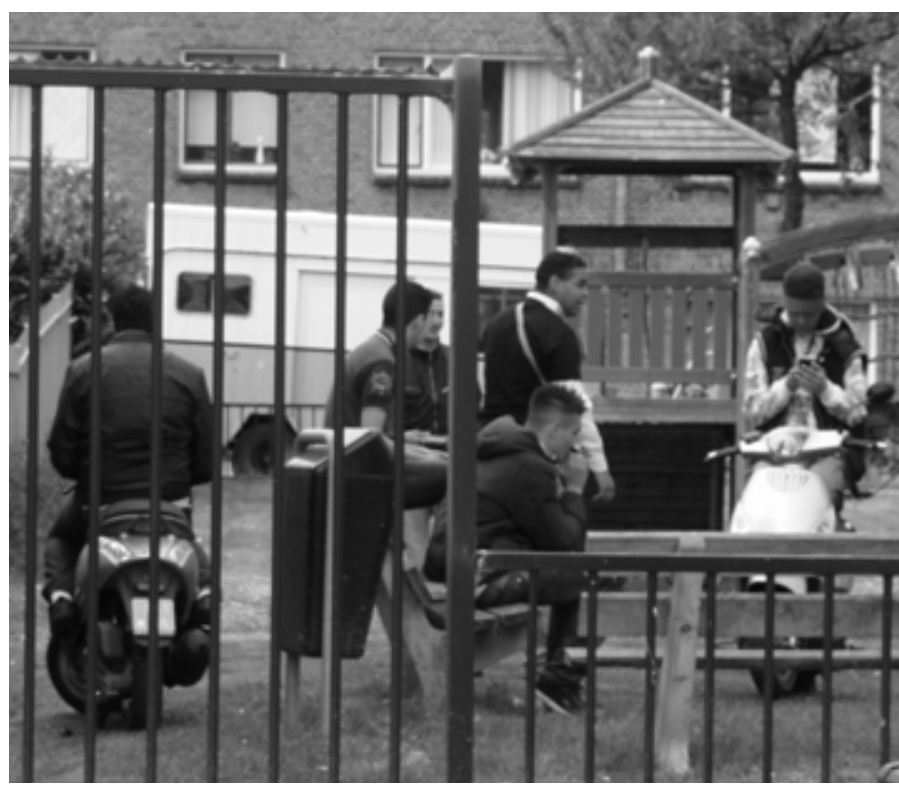

Er zijn ruimtelijke en sociale grenzen, waardoor vrouwen niet alle ruimtes bezoeken.

gedraag. Ik vind het ook belangrijk dat ik de dingen doe zoals ze horen. Ik denk altijd dat ik als moslimvrouw of Marokkaanse iets fout doe, dan telt ook gelijk dat moslim en Marokkaan zijn mee. En als ik gewoon een Nederlandse vrouw ben dan heb ik het idee dat dat helemaal niet telt. I $k$ heb toch een extra verantwoordelijkheid om te laten zien dat ik het wel kan allemaal."

In deze situaties worden de grenzen bevestigd. In weer andere situaties kiezen moslima's ervoor om niet deel te nemen aan activiteiten op typisch Nederlandse plekken, omdat zij van mening zijn dat zij aangestaard worden of omdat er zelfs sprake is van discriminatie. In deze gevallen is er sprake van een harde ruimtelijke grens:

"Ik ben nooit meer uitgeweest in Utrecht naar een discotheek, omdat mijn Marokkaanse vrienden toen niet naar binnen mochten. Ik voel de discriminatie net zo hard als hen, en dat doet erg zeer."

De grens wordt in deze situaties bevestigd door het gedrag van de dominante groep.

Hoewel de vrouwen in verschillende situaties grenzen onderwerp van onderhandeling maken, geven ze ook aan dat het bezoeken van plekken waarin zij niet een minderheid vormen en waarin weinig beperkingen ondervinden, hen soms meer vrijheid geeft dan het bezoeken van plekken waar dit niet het geval is. Op openbare plekken wordt bepaald gedrag verwacht en tegelijkertijd is er de verwachting dat moslima's dit gedrag niet vertonen. De NederlandsMarokkaanse vrouwen geven aan dat zij vaak moeten strijden tegen de oplegging van religieus-culturele verwachtingen van enerzijds de 'meerderheid' en anderzijds hun eigen familie. Grenzen onderhandelen en verleggen kan uiteindelijk een risico vormen. Vrouwen geven aan dat dit met name speelt als er kinderen in het spel zijn. Sommige vrouwen zijn zich erg bewust van veranderingen in hun eigen gedrag na de komst van kinderen. Ze proberen een voorbeeld te zijn voor hun eigen kinderen en houden hierdoor meer rekening met 


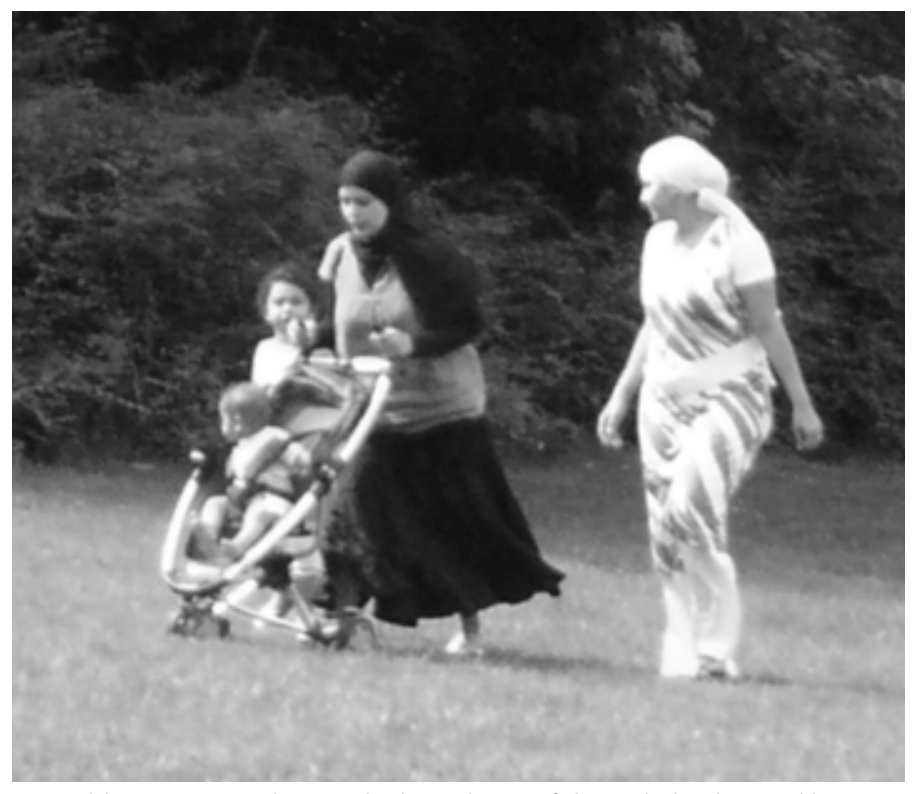

Bepaalde ruimtes worden minder bezocht en/of de Nederlands-Marokkaanse vrouwen houden rekening met de wijze waarop zij gekleed gaan.

mogelijke discriminatie en verwachtingen van hun familie en de meerderheid in de openbare ruimte. Dit betekent dat zij hierdoor bepaalde ruimtes niet of minder zullen bezoeken of wanneer zij bepaalde ruimtes wel bezoeken en hierbij rekening houden met de wijze waarop zij gekleed gaan.

Ook in Marokko ervaren Europese vrouwen grenzen die zijn gerelateerd aan percepties over wat acceptabel is. Sommige jonge vrouwen worden beperkt tijdens de vakanties door de aanwezigheid van een mannelijk familielid, zoals een broer of een neef. Zij worden geacht niet alleen op pad te gaan. Veel vrouwen gaan echter tijdens hun vakantie dagelijks het ouderlijk huis uit om verschillende vrijetijdsplekken te bezoeken, zoals stranden, waterparken en het stadscentrum. Eén vrouw beschrijft de instructies die haar moeder dagelijks geeft als zij en haar zussen naar het strand gaan:

"Ja, als we wakker worden dan gaan we naar het strand in Temera, dat is in de buurt van Rabat, of ik neem de auto. Sinds ik mijn rijbewijs heb, is het makkelijker want dan kan ik de auto nemen, en dan ga ik naar Bouznika of Mohammedia in de buurt van Casablanca. Maar we gaan altijd maar voor één dag en dan komen we terug. Mijn moeder laat ons nooit naar Casablanca alleen gaan, want Casablanca is, eh, een harde stad, chaos, chaos, dat zegt ze [...] . Dus ik ga gewoon naar Rabat, want het daar erg rustig en cool, niemand praat met je."

\section{Onderhandelen over en verleggen van grenzen kan een risico vormen}

Deze waarschuwing, om alleen naar bepaalde stranden te gaan en niet naar Casablanca, is een kwestie van het stellen van grenzen door ouders, maar het is ook een kwestie van het bewaken van grenzen door de vrouwen zelf. Vaak geven zij zelf de voorkeur aan de rustige omgeving van bepaalde badplaatsen boven de chaoti- sche sfeer van Casablanca waar de kans op ongewenste aandacht groter is. De vrouwen bepalen door deze keuzes hun eigen grenzen in hun vrijetijdsbesteding.

\section{Tot slot}

We hebben laten zien dat het onderhandelen van grenzen enerzijds een directe confrontatie met de ervaren barrières inhoudt, en anderzijds een proces waarbij de grenzen minder duidelijk zijn. Over het algemeen gaan vrouwen op zoek naar ruimtes waarin zij zoveel mogelijk zichzelf kunnen zijn. Dit zorgt ervoor dat zij bepaalde ruimtes vermijden door bijvoorbeeld ruimtes op te zoeken waar zij geen zichtbare minderheid vormen. Op andere momenten gaan zij de confrontatie aan en zoeken zij naar mogelijkheden om grenzen te overschrijden, en zo door onderhandeling wel zonder mannelijke familieleden naar het strand te kunnen gaan.

Deze onderhandelingen waren zelden eenvoudig of eenduidig en meestal gericht op het vinden van een balans tussen de verwachtingen van familie, van een in-groep gemeenschap van EuropeseMarokkanen, en van een out-group gemeenschappen van de andere Nederlandse en / of algemene Marokkaanse bevolking. Op individueel niveau zijn deze inspanningen wellicht niet revolutionair, maar gezamenlijk geven ze een idee hoe de grenzen van ruimtes worden onderhandeld en uitgebreid. Vrouwen bewaken de grenzen grotendeels zelf en houden hierbij rekening met hun eigen percepties over acceptabele en prettige ruimtes.

\section{Karin Peters (karin.peters@wur.nl) en Lauren Wagner (lauren. wagner@wur.nl) zijn beiden verbonden aan de leerstoelgroep Culturele Geografie van Wageningen Universiteit.}

\section{Literatuurselectie}

Bridge, G. \& S. Watson (2002) Lest power be forgotten: Networks, division and difference in the city. Sociological Review 50, no. 4 pp.505-524

Deem, R. (1986) All work and no play? The sociology of women and leisure. Milton Keynes: Open University Press.

Green, E. \& C. Singleton (2006) Risky bodies at leisure: Young women negotiating space and place. Sociology 40, no. 5 , pp.853-871

Peters, K. (2011) Living together in multi-ethnic neighbourhoods: The meaning of public spaces for issues of social integration. PhD thesis, Wageningen University.

Scraton, S. \& B. Watson (1998) Gendered cities: Women and public leisure space in the 'postmodern city' Leisure Studies 17, no. 2, pp. 123-137

Sijtsma, M. (2011) Negotiating the oppression of discrimination encountered in outdoor leisure: A study of Muslim women in the Netherlands. MSc thesis. Wageningen University,

Wagner, L. (2011) Negotiating diasporic mobilities and becomings: Interactions and practices of Europeans of Moroccan Descent on holiday in Morocco. PhD thesis, University College London. Yücesoy, E.U. (2006) Everyday urban public space: Turkish immigrant women's perspective. PhD thesis, Utrecht University. 